\title{
MANIFESTATION OF HARMFUL EFFECTS OF WATER IN THE SETTLEMENTS ON THE EXAMPLE TATARBUNARY DISTRICT OF ODESSA REGION
}

\author{
Miedviedieva O.O., postgraduate student, \\ mdvdv_olga@ukr.net, ORSID: 0000-0003-3575-0592 \\ Institute of Water Problems and Land Reclamation NAAS, Kyiv, Ukraine \\ str. Vasylkivska, 37, Kyiv, 03022, Ukraine
}

\begin{abstract}
One of the main manifestations of the harmful effects of water in the southern, central and eastern territories of Ukraine is the flooding of lands, and especially settlements (SM). For various reasons, reliable data on the extent of flooding are not available or they are incomplete and do not reflect the real picture. An objective assessment of the harmful effects of water can be given only on the basis of monitoring the level and hydrochemical composition of ground (GW) and surface waters. To do this, it is necessary to carry out systematic monitoring observations: to have a network of observation posts and the corresponding cartographic material.

The main purpose of the work is to show an effective approach to solving the issue of the negative impact of water on the example of 33 SM of the Tatarbunary district. Determine the current state of flooding, the chemical composition of groundwater aquifers to optimize managerial decision-making to prevent the development of dangerous geological and ecological processes. At the same time, the subject of the study was the factors of formation and dynamics of levels and the chemical composition of GW of the first aquifers from the surface, the correspondence of the chemical composition of water to the MPC for drinking needs.

To solve this problem, an approach is proposed consisting of five stages using GIS programs Arc Map, 3D analysis method. As a result of the work, the average values for the period 2011-2019 were calculated and were built within each SM in electronic form a map diagram of the GW level and the exposed capacity of aquifers; chemical composition and mineralization; for individual chemical components and exceeding the MPC for drinking water supply.

The approach indicated in this work allows us to assess the state of flooding and potential flooding in a separate oil reservoir and, at the same time, to obtain a complete picture of the state of flooding and water quality in dynamics at any time and period of the year and to make balanced engineering decisions to eliminate them.
\end{abstract}

Keywords: harmful effects of water, groundwater, flooding, potential flooding, monitoring, settlement, wells, chemical state of water.

Introduction. Since the beginning of the XXI century, especially in the last decade, all over the world, including Ukraine, there are manifestations of harmful effects of water, which is accompanied by flooding, inundation and, consequently, deterioration of water quality for various uses. This floods not only a large number of rural settlements (SM), but also large cities. Accurate data on the scale and causes of flooding in Ukraine for a number of different reasons, despite the existence of a number of organizations, currently does not exist or they are not complete and do not reflect the real picture.

This thesis is confirmed by the "Analytical Review ... for 2018" [1]. According to this document, in recent years "... mapping of areas of the flooding process is carried out little and unevenly." This is due to several reasons, the main of which is the low level of funding for monitoring and individual monitoring of groundwater levels (GWL).

The flooding process itself can be influenced by various factors, sources and criteria [2]. In this case, an objective assessment of the harmful effects of water can be given only on the basis of monitoring the level and hydrochemical composition of groundwater $(\mathrm{GW})$ and surface water. To do this, it is necessary to conduct systematic monitoring observations: to have a grid of observation points 
and appropriate cartographic material. The absence of observation regime wells (points) or their insignificant number does not allow to monitor the dynamics of the regime $\mathrm{GW}$ and does not allow to map the flooding processes in general for each SM. For these reasons, reliable data on the extent of flooding and inundation do not exist.

In general, flooding is a complex, harmful and dangerous hydrogeological phenomenon of natural and man-made origin, which occurs in the surface layer of soils and is expressed in water inflow, temporary or prolonged rise of groundwater close to the earth's surface, the harmful effects of these waters. It is widespread and covers the territory of many agricultural and forest lands, settlements, industrial and other facilities, which are mostly located at low hypsometric levels. This phenomenon causes a number of negative processes and consequences, including waterlogging, salinization, subsidence and landslides, changes in their water-physical and physico-chemical properties. As a result of flooding on agricultural lands, the conditions for the development of the root system of plants, orchards and vineyards are deteriorating, the vital activity of soil microorganisms is reduced, and soil fertility is reduced. In cities and villages in built-up areas there is flooding and waterlogging of underground space - bearing soils, foundations of residential buildings, utilities and structures, their stability, construction resource and durability decreases, seismic danger increases, green areas die. The high level of groundwater significantly complicates industrial and residential construction, does not allow the use of traditional technologies, increases the cost and timing of construction.

In our country, the problem of flooding together with flooding is gaining significant sociopolitical resonance. This is due, firstly, to the fact that the topic of dangerous phenomena and natural disasters has become open and widely covered in the media, while in Soviet times it was mostly closed and the main information was classified as "For official use". Secondly, the term "flooding" has become widely used when it comes to such a phenomenon as flooding, which occurs much more often than flooding. Third, water use in agricultural production in the private sector has increased. In the southern region, such growth occurs against the background of regular and intensive irrigation of homesteads. In some places, three vegetables were harvested - early radishes, early potatoes, tomatoes, cucumbers, peppers or eggplants. At the same time, the wear and tear of the water supply network has increased in settlements and water losses from it have increased, which significantly increases the threat of flooding processes. And clutter or construction of places of unloading GW (beams, ravines) and places of flood or rain water (bridges, pipe and other crossings) encourages even greater manifestation of the negative effects of water.

In Odessa region, according to [1], 983 state of emergency on the area of $20,575 \mathrm{~km}^{2}$ are considered flooded. This is $22.2 \%$ of the number of flooded state of emergency of Ukraine.

Analysis of recent research and publications. The analysis of the materials of the publications of the last years testifies to the almost practical absence of the publications of the specialists on the flooding of the state of emergency in the southern part of Ukraine. Most of the works and articles cover the situation in the western regions and they do not relate to classical flooding, but flooding, due to the harmful effects of rivers during floods $[3,4]$.

Specialists of the Odessa Hydrogeological and Reclamation Expedition (now SS "Black Sea Center for Water Resources and Soils") studied the state of flooding of rural emergencies in the southwestern part of Odessa Region. Their work is thoroughly covered in scientific papers and was the basis for the compilation of manuals $[2,5,6]$. In addition, many materials and reports are in the above institution in the form of economic contract work and planning information and reports (stock materials of the organization). But now, these monitoring observations, due to optimization, are significantly reduced, and professional information is needed for new administrative entities (districts, individual territorial communities (ITC)) to address socio-economic issues and engineering protection of their territories. The author [2,7-13] also contributed to the study of these problems.

The aim of the work is to show an effective approach to solving the problem of negative water impact on the example of Tatarbunary district, to determine the current state of flooding, chemical status of soil aquifers and prospects for their elimination and improvement to optimize management decisions to prevent dangerous geological and environmental processes. The subject of the study were the factors of formation and dynamics of levels and chemical composition of groundwater first from the surface of aquifers, the correspondence of the chemical composition of water MPC for drinking needs.

Bulletin of Odessa State Academy of Civil Engineering and Architecture, 2021, no. 82, page 133-140 
Materials and methods of research. Analysis of materials and field studies were conducted within 33 SM Tatarbunary district. The research covers the period 2011-2019. At the same time, the data of annual monitoring observations on the dynamics of GWL, their quality and the state of flooding were considered. The actual depths, regularities and dynamics of changes in their oscillations were established during the analysis of GWL. Actual depths were compared with critical ones, which were accepted according to normative documents [12-14].

The following research methods were used during the works:

- Empirical method - conducting field and in-house work (observation of GWL dynamics, GWL measurements, water sampling for chemical analysis, comparison of the obtained data) taking into account [12-15].

- Methods of theoretical research, namely the formalization of the obtained data in the form of construction of various maps and maps and verification of some assumptions using field materials.

- Universal research methods - analysis of the obtained systematized data using GIS programs Arc Map, the method of interpolation 3D analysis [16, 17].

Methods of work. The main problem in the study of the state of flooding of the SM was and is the small number or complete absence of the regime-monitoring network for GWL. This problem (absence of regime-observation wells) was solved by measuring GWL in the exposed aquifers of the Pliocene-Quaternary age (the first aquifer from the surface), which in the SM is exposed in the form of wells.

The work was performed in several stages. At the first stage, in-house training was conducted, which consisted in the study of literary and stock materials of various organizations and institutions in the area of work; collection of official data on the state of emergency of the district: number of settlement councils, state of emergency, area of state of emergency, number of buildings and yards, availability of wells, artesian wells, water tanks, water supply sources, water supply and sewerage network, etc.; preparation of cartographic material 1:10000 scale: copying from general plans, tracing, making copies, drawing on maps of the regime-observation network; development and drawing up of plans of field works: preparation of "draft" maps, definition and drawing up of symbols, definition of routes. The second stage is the implementation of field work, which is performed on the previously mentioned routes. Thus in SM, practically on each well, measurements of GWL and capacity of the exposed aquifer are carried out. Measurements of GWL are carried out on all hypsometric marks taking into account geomorphological conditions; the number of the well, the data on SM measurements are taken out on the "rough" maps and are entered to the bottom in the "Journal of GWL measurements"; at high standing of GWL (less than 2,0m) or at the request of inhabitants, inspections of buildings and basements are carried out, the level of standing of water, or dampness on walls and other displays of negative action of waters is fixed; during the survey, additional sources of water (lakes, reservoirs, ponds, ponds, water supply, sewerage, etc.) and pollutants (landfills, cattle burial grounds, chemical warehouses, farms, etc.) are established; the causes and possible places of "flooding" of territories are determined. At the third stage the in-house processing of the materials received as a result of carrying out the second stage (field) is carried out and points of hydrochemical test and a route of movement are planned. At the stage of the fourth stage, water samples are taken at the planned points and at the same time additional studies of "emergency" areas of the state of emergency are carried out.

The results of field research, the results of chemical analysis of water, are summarized and analyzed, maps of mineralization and chemical composition of the GWL.

The author of the work since 2010 has directly participated in the above works in Tatarbunary, Tarutyn, Kiliya and Izmail districts. In the process of work, this approach to solving the problem of harmful effects of water was slightly changed and adapted to changes in the administrative system, and also proposed and implemented the fifth stage - analysis of the data and their systematization using GIS programs Arc Map, method interpolation 3D analysis. At this stage, a cartographic basis was created within each SM. Each observation point was attached to the base and then electronic maps for various purposes were built.

This approach was first used, with the exception of the fifth stage, in 2006 for works in the Tarutyn district and partly in the Tatarbunary district. Subsequently, the author surveyed other state of emergency and the district center of Tatarbunary. 
A total of 1,075 wells and 16 wells were explored within the district. 350 points (16 wells and 334 wells) were selected for monitoring.

Flooding, as mentioned above, is a multifactorial process, but in most cases, as our research shows, especially in recent years, depends on weather and climatic conditions, the technical condition of the culvert, the availability of drainage, and so on. The share of state irrigation in these cases, especially in recent years, is almost zero. According to regulations, flooded and potentially flooded areas are distinguished $[18,19]$. Flooded areas - areas where permanently or temporarily for a fairly long period (a month or more) groundwater rises above the limit depths. Potentially flooded areas are areas where the conditions for classifying them as flooded areas have not yet developed, but this is possible by forecast or by coincidence of current factors and causes. In our steppe zone, flooded areas are those where GWL lies in the range from 0.0 to $2.0 \mathrm{~m}$; potentially flooded -2.0-3.0 $\mathrm{m}[18,19]$.

Research results. Within the district, flooded and potentially flooded areas are observed mainly in five emergencies, namely in the villages of Borysivka, Spaske, Strumok, Nerushay and Diviziya. The total area of flooding, during the observation period, in these SM varied from 18 to 70 ha, potential flooding - 37-90 ha and does not exceed $10 \%$ of the total area of these SM, with a variation from 3.3 to $9.5 \%$. At the same time, 83 to 219 yards fell into this zone (Table 1). The reasons for the presence of such areas are mostly natural, and the variation of areas over different years is explained by weather and climatic conditions of the year and the study period.

Table 1 - Distribution of areas of flooding and potential flooding by the depth of GWL

\begin{tabular}{|c|c|c|c|c|c|c|c|c|c|}
\hline \multirow{3}{*}{ Year } & \multirow{3}{*}{ \# SM } & \multicolumn{2}{|c|}{ Characteristic SM } & \multicolumn{6}{|c|}{ Distribution GWL, m } \\
\hline & & \multirow{2}{*}{ area, ha } & \multirow{2}{*}{$\begin{array}{c}\text { number of } \\
\text { yards, } p\end{array}$} & \multicolumn{2}{|c|}{$\begin{array}{l}\text { flooded } \\
<1,0-2,0\end{array}$} & \multicolumn{2}{|c|}{$\begin{array}{c}\text { potentially flooded } \\
2,0-3,0\end{array}$} & \multicolumn{2}{|c|}{$\begin{array}{c}\text { not flooded } \\
>3,0\end{array}$} \\
\hline & & & & area, ha & $\begin{array}{c}\text { number of } \\
\text { yards, } p\end{array}$ & area, ha & \begin{tabular}{|c} 
number of \\
yards, $p$
\end{tabular} & area, ha & $\begin{array}{c}\text { number of } \\
\text { yards, } p\end{array}$ \\
\hline 2011 & 5 & 1684 & 3477 & 70 & 78 & 90 & 141 & 1524 & 3258 \\
\hline 2012 & 5 & 1684 & 3477 & 39 & 49 & 66 & 95 & 1579 & 3333 \\
\hline 2013 & 5 & 1684 & 3477 & 45 & 53 & 74 & 103 & 1565 & 3321 \\
\hline 2014 & 5 & 1684 & 3477 & 39 & 42 & 64 & 84 & 1581 & 3351 \\
\hline 2015 & 5 & 1684 & 3477 & 31 & 33 & 49 & 66 & 1604 & 3345 \\
\hline 2016 & 5 & 1684 & 3477 & 39 & 42 & 63 & 90 & 1582 & 3345 \\
\hline 2017 & 5 & 1684 & 3477 & 40 & 46 & 67 & 98 & 1577 & 3333 \\
\hline 2018 & 5 & 1684 & 3477 & 40 & 46 & 57 & 98 & 1577 & 3333 \\
\hline 2019 & 5 & 1711 & 3477 & 18 & 27 & 37 & 56 & 1656 & 3391 \\
\hline
\end{tabular}

Chemically, groundwater is heterogeneous, variegated. In hydrochemical terms, the vast majority of groundwater, according to the classification of O.A. Alokin [20], belongs to the sulfate and chloride class, sodium group, II and III classes (water of moderate mineralization and highly mineralized). Waters of moderate mineralization are common in areas with high GW. According to [21], the practical majority of waters exceeds the MPC in terms of sulfates, chlorides, nitrates, mineralization and hardness - from insignificant to 80 times. To obtain the above information, the average values were calculated and were built within each SM in the electronic form of the GWL map and the exposed capacity of aquifers; maps of chemical composition and mineralization GW; maps of individual chemical components and exceeding the MPC for drinking water supply in terms of sulfates, chlorides, nitrates, nitrites, phosphates, mineralization and hardness (Fig. 1).

Conclusions. Flooding, as a factor, takes place in the Tatarbunary district of Odessa region. Its manifestations and intensity depend on many factors, but the main ones are the technical condition of hydraulic structures (bridges, crossings), drainage (where it is) and the culvert network in combination with weather and climatic conditions. The role of irrigation with government systems is insignificant, especially in recent years, due to a significant reduction in irrigation. Within the district with 33 state of emergency in $40 \%$, under certain weather and climatic conditions, flooded and potentially flooded areas may be detected. 
a)

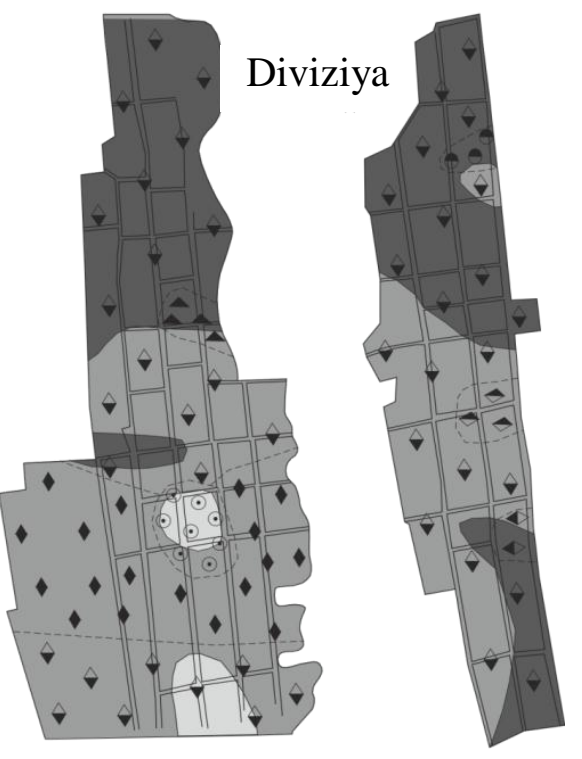

c)

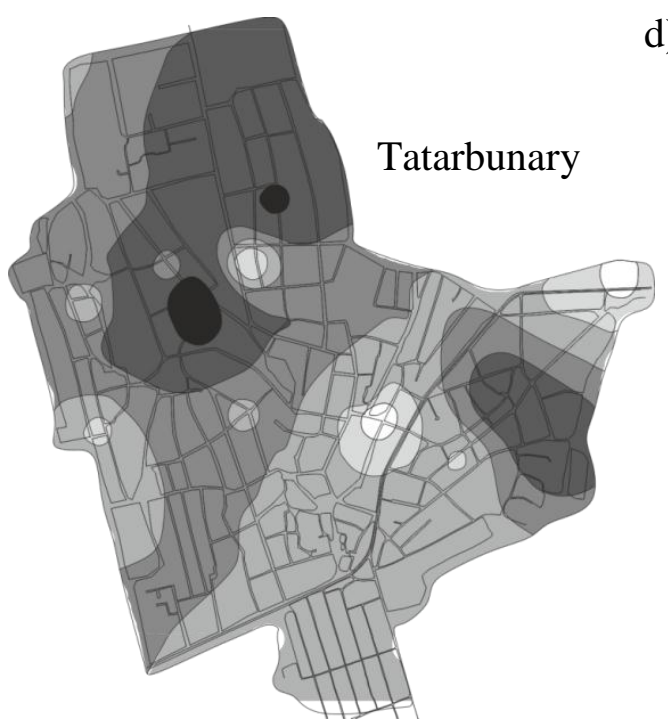

b)

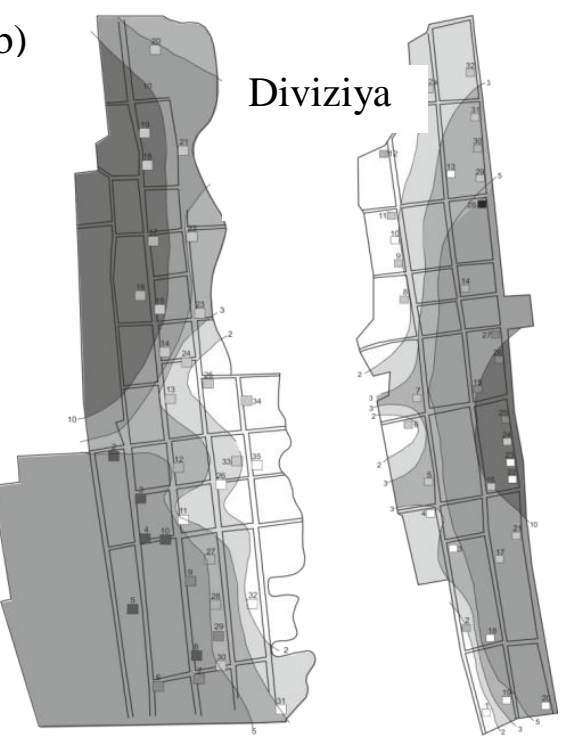

d)

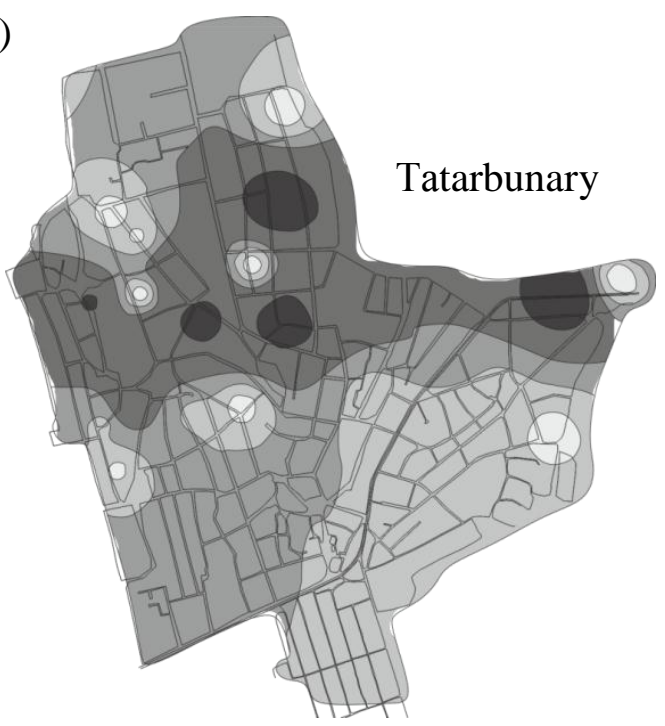

a) Exposed power of the aquifer $(\mathrm{m})$

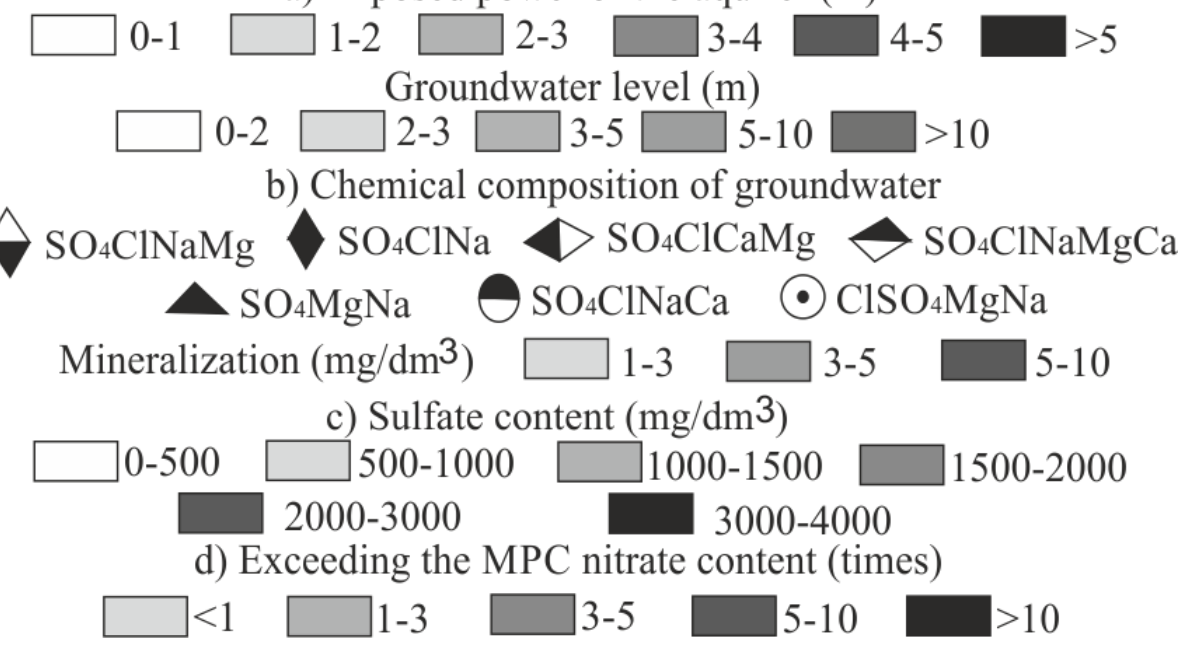

Fig. 1. Map: a - exposed power of the aquifer and groundwater level within the village of Divisiya; $b$ - mineralization and chemical composition of groundwater; $c$ - sulfate content; $\mathrm{d}$ - exceeding the MPC nitrate content within Tatarbunary town 
In general, the main reasons for the presence of flooded and potentially flooded areas within the Tatarbunary district are:

- naturally high groundwater levels in the valleys of small rivers Kogylnyk, Hadzhider, Nerushay, Tsarychanka and in the beams within the state of emergency;

- support of groundwater within the influence of Nerushay and Dmytrivka reservoirs;

- wedging of groundwater of the Pontic aquifer;

- uncontrolled watering on homesteads in the western part of the district;

- absence or clutter of the drainage and discharge network in some villages, absence of storm drains, clutter of water checkpoints.

Thy approach indicated in this work, using GIS programs Arc Map, a method of interpolation 3D analysis, allows you to assess the state of flooding and potential flooding in a particular SM, a particular territorial community, district and region as a whole. The first four stages are more costeffective. In the future, monitoring observations can be carried out only on the reference points and thus obtain a holistic picture of the state of flooding and water quality in the dynamics. In addition, you can make the presence and technical condition of hydraulic structures, the direction and location of possible flooding, and so on on a ready-made cartographic basis.

It is this information about the state of emergency makes it possible not only to identify areas with manifestations of harmful effects of water, but also to identify places and priority areas where it is possible to prevent the manifestations of these negative phenomena. It is much better to prevent than to overcome the consequences, which are not only purely economic but also social.

The results of this approach, its relevance for solving the problem of harmful effects of water are clearly illustrated by the example of Tarutyn district, where after the recommendations and work, according to monitoring studies, the problem of flooding in five settlements was removed. As for the city of Tatarbunary, the problems of harmful effects of water are identified and studied within the program of the city council "Clean Sources for 2018-2020", which currently helps to identify sources that can and should be restored, thereby minimizing the irrational use of community funds. for water supply of the population with water. Thus, the "implementation" was obtained, which began to be implemented in the second half of 2020.

\section{References}

[1] Analitychnyi ohliad stanu tekhnohennoi ta pryrodnoi bezpeky v Ukraini za 2018 rik. UkrNDITsZ, 2019.

[2] O.O. Miedviedieva, O.Iu. Miedviediev, "Poperedzhennia pidtoplennia silskykh naselenykh punktiv - odne z holovnykh zavdan ekolohichnoi bezpeky v XXI stolitti", Ekonomikoheorhafichna osvita i natsionalna samosvidomist: aktualni problemy yikh formuvannia :VII vseur. nauk.-prak. konf. studen. i molod. vchenykh. Dniprodzherzhynsk, 2012, pp. 168-171.

[3] M.I. Romashchenko, D.P. Savchuk, "Katastrofichna povin i zatoplennia na Zakarpatti u berezni 2001 p", Vodne hospodarstvo Ukrainy, no. 1-2, pp. 4-10, 2002.

[4] M. Khvesyk, I. Petruk, "Ekonomiko-ekolohichne obhruntuvannia stratehychnykh rishen shchodo zakhystu vid shkidlyvoi dii vod naselenykh punktiv ta silskohospodarskykh uhid Karpatskoho rehionu", Vodne hospodarstvo Ukrainy, no. 1-2, pp. 31-33, 2005.

[5] O.Iu. Miedviediev, "Pidtoplennia naselenykh punktiv Odeshchyny: diisnist i perspektyvy", Vodne hospodarstvo Ukrainy, no. 3, pp. 35-39, 2006.

[6] Metodyka provedennia kompleksu monitorynhovykh robit u systemi Derzhvodhospu: posibnyk 1 do VBN 33.5.5-01-97. Institut hidrotekhniky i melioratsii UAAN, Kyiv, 2002.

[7] O.O. Miedviedieva, "Khimichnyi sklad ta riven vody pershoho vid poverkhni horyzontu v mezhakh naselenykh punktiv Tatarbunarskoho raionu Odeshchyny", Vodne hospodarstvo Ukrainy, no.1, pp. 44-47, 2016.

[8] O.O. Miedviedieva, "Vyvchennia shkidlyvoi dii vod prykladi s.Tropivka Tatarbunarskoho raionu Odeshchyny", Upravlinnia vodnymy resursamy $v$ umovakh zminy klimatu : tez. dop. mizhnarodna nauk.-prak. konf. Kyiv, pp. 45-46, 2017. 
[9] O. Miedviedieva, O. Dyniak, "Monitoring of flooding processes development in Odessa region on the example of v. Nerushai of Tatarbunary region", Monitoring of Geological Processes and Ecological Condition of the Environment : XI International Scientific Conference, 2017.

[10] O.O. Miedviedieva, "Yakist hruntovykh vod $\mathrm{v}$ mezhakh naselenykh punktiv na uzberezhzhi Sasykskoho vodoskhovyshcha", Pryroda dlia vody. materialu mizhnarodna nauk.-prak. konf. Kyiv, pp. 120-121, 2018.

[11] O. Miedviedieva, O. Dyniak, "The hydrochemical mode and quality of subsoil waters of settlements are on the coast of Sasyk storage pool", Theoretical and Applied Aspekts : XVII International Conference, 2018.

[12] O.O. Miedviedieva, "Pidkhid do vyvchennia shkidlyvoi dii vod v mezhakh silskykh naselenykh punktiv Odeshchyny", Hidroheolohiia: nauka, osvita, praktyka : material V nauk.-prak. konf. Kharkiv, pp. 36-38, 2018.

[13] O. Miedviedieva, O. Dyniak, "Stady of factors of formation of groundwater levels within the rural settlements of the Tatarbunary district", Theoretical and Applied Aspekts : XVIII International Conference, 2019.

[14] VND 33-5.5-07-99. Organizacziya rabot po obsledovaniyu i oczenke podtopleniya selskokhozyajstvennykh ugodij i selskikh naselennykh punktov. Kiev, 1999.

[15] VND 33-1.1-17-2001. Instruktsiia $\mathrm{z}$ vidboru i pidhotovky prob vody ta hruntu dlia provedennia vymiriuvan v laboratoriiakh Derzhvodhospu Ukrainy. Derzhavnyi komitet Ukraine po vodnomu gospodarstvu. Kiev, 2001.

[16] ESRI White paper ArcGis 3D Analyst. 3D vizualizacziya, topograficheskij analiz, postroenie poverkhnostej. 2002.

[17] Arc GIS Desktop. [Online]. Available: https://desktop.arcgis.com/ru/arcmap/

[18] VND 33-5.5-07-99 Organizacziya rabot po obsledovaniyu i oczenke podtopleniya selskokhozyajstvennykh ugodij i selskikh naselennykh punktov. Gosudarstvenny j komitet Ukrainy po vodnomu khozyajstvu. Kiev, 1999.

[19] DBN V.1.1-25-2009 Inzhenernyi zakhyst terytorii ta sporud vid pidtoplennia ta zatoplennia. K.: Minrehionbud Ukrainy, 2010.

[20] P.V. Gordeev, V.A. Shemelina, O.K. Shulyakova, Rukovodstvo $k$ prakticheskim zanyatiyam po gidrogeologii, Vysshaya shkola, Moskva,1981.

[21] SanPiN no. 384-96. Sanitarnye pravila i normy po ustrojstvu i soderzhaniyu kolodczev i kaptazhnikh rodnikov, ispolzuemykh dlya deczentralizovannogo khozyajstvennopitevogo vodosnabzheniya. Derzhavni Sanitarni pravila ta normi. San Pin no. 384. K.: MOZ Ukrayini, 1996.

\title{
ПРОЯВИ ШКІДЛИВОЇ ДІЇ ВОД В НАСЕЛЕНИХ ПУНКТАХ НА ПРИКЛАДІ ТАТАРБУНАРСЬКОГО РАЙОНУ ОДЕСЬКОЇ ОБЛАСТІ
}

\author{
Мєдвєдєва O.O., аспірант, \\ mdvdv_olga@ukr.net, ORCID: 0000-0003-3575-0592 \\ Інститут водних проблем і меліорації НААН \\ вул. Васильківська, 37, м. Київ, 03022, Україна
}

Анотація. Одним з основних проявів шкідливої дії вод в південних, центральних і східних територіях України є підтоплення земель, та особливо, населених пунктів (НП). Достовірні дані про масштаби підтоплення, з різних причин, відсутні або вони не повні і не відображають реальну картину. Об'єктивну оцінку шкідливої дії вод можна давати тільки на базі спостережень за рівнем і гідрохімічним складом грунтових (ГВ) і поверхневих вод. Для цього необхідно проводити систематичні моніторингові спостереження: мати мережу спостережних пунктів і відповідний картографічний матеріал.

Метою роботи є показати дієвий підхід до вирішення питання про негативну дію вод на прикладі 33 населених пунктів Татарбунарського району. Визначити сучасний стан підтоплення, хімічного складу грунтових водоносних горизонтів для оптимізації прийняття управлінських рішень щодо попередження розвитку небезпечних геологічних і екологічних

Bulletin of Odessa State Academy of Civil Engineering and Architecture, 2021, no. 82, page 133-140 
процесів. При цьому предметом дослідження були чинники формування, динаміка рівнів $\mathrm{i}$ хімічний склад грунтових вод перших від поверхні водоносних горизонтів, відповідність хімічного складу води ГДК для питних потреб.

Для вирішення даної проблеми запропоновано підхід, що складається 3 п'яти етапів із застосуванням ГІС програм Arc Мар, методу 3D аналіз. В результаті роботи були прораховані середні значення за період 2011-2019гг. і були побудовані в межах кожного НП в електронному вигляді картосхеми рівня ГВ і розкритої потужності водоносних горизонтів; хімічного складу і мінералізації; по окремим хімічним компонентам і перевищенні ГДК для питного водопостачання.

Зазначений, в даній роботі, підхід дозволяє оцінювати стан підтоплення і потенційного підтоплення в окремому НП, i, при цьому, отримувати цілісну картину стану підтоплення та якості вод в динаміці в будь-який час і період року та приймати для їх усунення зважені інженерно-технічні рішення.

Ключові слова: шкідлива дія вод, грунтові води, підтоплення, потенційне підтоплення, моніторинг, населений пункт, криниці, хімічний стан води.

\title{
ПРОЯВЛЕНИЕ ВРЕДНОГО ВОЗДЕЙСТВИЯ ВОД В НАСЕЛЕННЫХ ПУНКТАХ НА ПРИМЕРЕ ТАТАРБУНАРСКОГО РАЙОНА ОДЕССКОЙ ОБЛАСТИ
}

\author{
Медведева О.О., аспирант, \\ mdvdv_olga@ukr.net, ORSID: 0000-0003-3575-0592 \\ Институт водных проблем и мелиораџии НААН, Киев, Украина \\ Ул. Васильковская, 37, г. Киев, 03022, Украина
}

Аннотация. Одним из основных проявлений вредного воздействия вод в южных, центральных и восточных территориях Украины является подтопление земель, и особенно, населенных пунктов (НП). Достоверные данные о масштабах подтопления, по разным причинам, отсутствуют или они не полные и не отображают реальную картину. Объективную оценку вредного воздействия вод можно давать только на базе слежения за уровнем и гидрохимическим составом грунтовых (ГВ) и поверхностных вод. Для этого необходимо проводить систематические мониторинговые наблюдения: иметь сеть наблюдательных пунктов и соответствующий картографический материал.

Основной целью работы показать действенный подход к решению вопроса о негативном воздействии вод на примере 33 НП Татарбунарского района. Определить современное состояние подтопления, химического состава грунтовых водоносных горизонтов для оптимизации принятия управленческих решений по предупреждению развития опасных геологических и экологических процессов. При этом предметом исследования были факторы формирования и динамика уровней и химический состав ГВ первых от поверхности водоносных горизонтов, соответствие химического состава воды ПДК для питьевых нужд.

Для решения данной проблемы предложен подход, состоящий из пяти этапов с применением ГИС программ Arc Мар, метода 3D анализ. В результате работы были просчитаны средние значения за период 2011-2019гг. и были построены в пределах каждого НП в электронном виде картосхемы уровня ГВ и вскрытой мощности водоносных горизонтов; химического состава и минерализации; по отдельным химическим компонентам и превышении ПДК для питьевого водоснабжения.

Указанный, в данной работе, подход позволяет оценивать состояние подтопления и потенциального подтопления в отдельном НП и при этом получать целостную картину состояния подтопления и качества вод в динамике в любое время и период года и принимать для их устранения взвешенные инженерно-технические решения.

Ключевые слова: вредное воздействие вод, грунтовые воды, подтопление, потенциальное подтопление, мониторинг, населенный пункт, колодцы, химическое состояние воды.

Стаття надійшла до редакції 27.10.2020 